\title{
Feminism: an Overview
}

Preeti Bala

Ph.D. course Research scholar,

P.G .Department of English and Research Centre,

Magadh University, Bodhgaya, India

preetisingh678@gmail.com

Abstract

Feminism is an ideology and a humanistic philosophy that assimilate men and women for the uplift and development of the society. It also stands for the system of ideas which has to do with the changing conditions of women in the historic evolution of the human race. Feminism emerges as a concept that can encompass both an ideology and movement for socio political change based on a critical analysis of male privilege and women's subordination within any given society. It is the advocacy of social equality for men and women, in opposition to patriarchy and sexism.

Key Words: Feminism, Ideology, Philosophy,Social Equality, Subordination.

Feminism which later termed as 'womanism' is a serious attempt to formulate the issue and find solution to gender problems. It is one of the philosophical concepts that has raised a lot of controversies in all human societies. It is an ideology and a humanistic philosophy that assimilate men and women for the uplift and development of the society. It also stands for the 
system of ideas which has to do with the changing conditions of women in the historic evolution of the human race. Feminism emerges as a concept that can encompass both an ideology and movement for socio political change based on a critical analysis of male privilege and women's subordination within any given society. It is the advocacy of social equality for men and women, in opposition to patriarchy and sexism. However, feminism views the personal experiences of women and men through the lens of gender, that is how we think of ourselves (gender identity), how we act (gender roles), and how our sex social standing (gender stratification) are all rooted in the operation of the society. it is another contemporary movement that is seeking to rethink Philosophy. It is a humanistic philosophy that incorporates as well as unites men and women for uplift and development of the society. Feminism is sometimes, caricatured as a movement of political reaction, but from a feminist's perspective, this constitutes a rather transparent strategy to undermine the philosophical authenticity of feminist thinking.

The term 'feminism' has its origin from the Latin word 'femina' means 'woman' and thereby refers to the advocacy of woman's rights, of "equality of sexes". The concept of feminism dates back to the very beginning of patriarchic domination. Age long suppression and torture mental, physical and emotional has forced her to lift the cudgels and stand up to fight the male chauvinistic society. Previously, women were deprived of the privileges to education whereas men were given all the facilities and prerogatives in this field. In the West, the book of Genesis has served as the primary source for definitions of gender and morality. Eve has represented the fundamental character and identity of all women from the last two hundred years. Eve represents everything about a woman that a man should guard against. Eve is woman, and because of her the prevalent belief in the west has been that all women are by nature disobedient, guileless, weak- willed, prone to temptation, evil, disloyal, deceitful, seductive and motivated in their thoughts and behavior purely by self - Interest. The story of 
Eve has served over the centuries as the principal document in the west in support of measures and laws to curtail the actions, rights and status of women. The pseudo- St Paul in his pastoral epistle to St. Timothy cites Genesis as the reason why women should not be allowed to teach or to tell a man what to do:-

For I do not allow woman to teach, or to exercise authority over men; but she is to keep silent. Since Adam was formed first, then Eve. Adam was not deceived, but the woman was deceived and became a transgressor. (6)

The word 'feminism 'was first coined around 1830 by a French utopian writer, Charles Fourier. It did not became familiar to the people until 1892, when a female politician actress Marguerite Durand called a convention to demand female rights in society. One of the main reasons the women's rights movements gained ground at the end of nineteenth century was that women began to realize that it is unfair for them to be constantly under the power of men simply males. Moreover, they found themselves compelled to change the social role of women from one wholly determined by men into a new equal one. It is ironic, however, that the first person to become aware of the unjust social condition of women and to demand fair treatment of females in society was not a woman but a man. His name was Poulain de La Barre, a seventeenth century theologian who published a tract entitled "Essays concerning the equality of men and women" in1673. In this tract, he straightforwardly points out that women are, by nature, no less intelligent than men, and that they would be able to engage in both creative and intellectual vocations if they are provided with the opportunity to study at educational institutions as men were.

The feminist literary criticism is the direct product of the "women's movement" of the1960's. Women struggled for equal rights in the western world. After the struggle the main 
demand of the women were fulfilled in most western countries, such as the right to own property, access to schools and universities and the right to vote. However, women soon found out that this formal equality had not led to a significant change in their actual social and economic circumstances. Feminist criticism, a case in point, is difficult to define because it has not yet been codified into a single critical perspective. Instead, its several shapes and directions vary one country to another, even from one critic to another. The premise that unites those who call themselves feminist critics is the assumption that western culture is fundamentally patriarchal, creating an imbalance of power that marginalizes women an their work. The sentiments of the famous feminist thinker Rebecca West are echoed in the following lines :-

I myself have never been able to find out what feminism is; I only know that people call me a feminist whenever I express sentiments that differentiate me from a doormat or prostitute. (6)

Feminism's key assumption is that gender roles are pre- determined and the woman is trained to fit into those roles. This means that roles like "daughter" or "mother" are not natural but social became the woman has to be trained think, talk, act in particular ways that suit the role. Beauvoir rightly asserts, "One is not born, but rather becomes a woman".

The concern with 'conditioning' and 'socialization' supports a key set of distinctions, between the terms 'feminist', 'female' and 'feminine'. As Toril Moi explains, the first is 'a political position', the second ' a matter of biology', and the third 'a set of culturally defined characteristic'. The distinction between the second and third of the phases lies much of the force of feminism. Feminist theory argues that the representation of women as weak, docile, innocent, seductive or irrational- sentimental is rooted in and influences actual social conditions, where she does not have power, is treated as a sex- object or a procreating machine, has fewer political and financial rights and is abused. 
Feminism ,therefore, is a world view that refuses to delink art from existing social conditions and practices. Feminism explores the cultural dimensions of the woman's material life. Feminist literary- cultural critics assume that cultural texts such as cinema, TV, music, painting parallel and duplicate real- life power struggles between genders. Cultural texts naturalize oppression of women through their stereo- typical representation of women as weak, vulnerable, seductress, obstacle, sexual object or a procreating device. Feminists pointed out, for example, that in the $19^{\text {th }}$ century fiction very few women work for a living, unless they are driven to it by dire necessity. The focus of interest in these works is on the heroine's choice of marriage partner, which will decide her ultimate social position and exclusively determine her happiness and fulfillment in life, or her lack of these. The task of criticism, therefore, is to reveal the underlying ideologies within these texts because these ideologies are instrumental in continuing women's oppression.

Thus feminist cultural theory analysis prevalent gender roles as they are represented in cultural forms like literature, cinema, advertisement; an approach that focus on how such representation of women reflect, and are connected to actual life and social conditions. Feminism's key political and theoretical stance is this: The inequalities that exist between men and women are not natural but social, preordained but created by men do that they retain power. Religion, the family, education, the art, knowledge system are all social and cultural structures that enable the perpetual reinforcement of this in equality these structures are effective mean of reinforcing male domination because they do not appear oppressive. They retain power because, with their ability persuade, the structures convince the woman that destined to be subordinated. Cultural structures are therefore ideological; providing a system of beliefs that seek and attain the woman's consent to be subordinated. Feminist theory work to unpack these ideologies of dominance. So it analyses gender relation, how gender relations are constructed and experienced. 
Some of western feminist discourses on third world women categorize 'third world women' as a homogenous unitary group regardless of their diverse multiple struggles and histories against racism, sexism, colonialism and imperialism. It can not be justified if we classify 'third world women' as a homogenous group of women because their experiences as a woman differ according to their contexts, background and historical location. In order to analyze women's situation by using intersectionality theory, third world feminist theories emphasize on the complex interrelationship between feminism, and antiracism, anticolonialism, political struggles, which shape third world women's experiences and histories differently. For instance, If we consider the example of black, white or Asian women, they all have various diverse histories due to the specific "particular inheritance of post-fifteenthcentury Euro American hegemony: the inheritance of slavery, enforced migration, plantation and indentured labor, colonialism, imperial conquest and genocide" (Mohanty10). Hence, third world feminists urge to rewrite the history of third world women based on their specific contexts, background, struggles they face, and also, 'day-to-day strategies of survival'.

Feminist situation in India retains a distinctive dispensation. For most Indians, the term' feminism' means nothing, if anything; the term has acquired many negative connotations in recent years. Indian society has always been highly hierarchical. The several hierarchy within the family concreting age, sex and ordinal position, congenial and fine relationship have been maintained with ruling power very strictly. The western feminist thought and the feminist movements had some influence on the woman's movement in developing countries like India. Eventully, feminism as it exists today in India has gone beyond its western counterparts. As Uma Narayan rightly puts it,

Third world feminism is not a mindless mimicking of western agenda in one clear and simple sense. Indian feminism is clearly a response to the issue related to Indian women. (243) 
After 1960s recent form of feminism that came to existence has become an evolving socio-political movement. It aims at understanding the power structures in the society, male domination, social practices and social institutions, which are instrumental in assigning a marginalized position to women. Feminist theory also invents the strategies to transfigure the social structures, which can help in the emancipation. The strong wave in the 1960s and 1970s has been proved instrumental towards women's discourse. In 1980s, Feminism concentrated on transfiguring the individual fields. In 1990s a crucial role began in directing academic focus on the concern of the issues of "otherness", differences and questions of marginality. The concept of feminism awakens fundamental queries related to reading, writing and the teaching of literature. It works as a political practice and an interdisciplinary tool for social and cultural analysis. Feminism has widely transformed the precision of life and literature.

Overviewing all, feminism is a socio- political orientation that seeks to eliminate bias based on gender and to value women's achievement, experience and perspectives. A school of thought that attempts to describe, explain and analyze the conditions of women's lives, that is, a way of viewing the world and proposes strategies for activism and action to ameliorate the conditions in which women live and work. 


\section{Works Cited}

Beauvoir, Simon De. The Second Sex. Trans. S.M. Parshley. London: Pan Book, 1988. Print.

Barry, Peter. Beginning Theory: An Introduction to Literary and Cultural Theory. U.K: Manchester University Press,2008. Print.

Christopher, Witcome. Eve and The Identity of Women. January 2000. http://www.witcome.sbc.edu/eve-women/html. Web.

Moi, Toril. Sexual/Textual Politics: Feminist Literary Theory. U.S.A: Routledge, 1988. Print.

Mohanty, Chandra Talpade. Feminism Without Borders: Decolonizing Theory, Practicing Solidarity. London: Duke University Press, 2003. Print.

Narayan, Uma. Dislocating Cultures: Identities, Traditions and Third World Feminism. New York: Routledge, 1997. Print.

Nair, Pramod Kumar. Contemporary Literary and Cultural Theory. New Delhi: Pearson, 2009. Print. 